\title{
WILDERNESS PRESERVED: NATURE SASKATCHEWAN'S SANCTUARIES
}

\section{D.P.PESCHKEN, 2900 Rae Street, Regina, SK S4S 1R5, e-mail:peschken@accesscomm.ca}

\section{Introduction}

Nature Saskatchewan administers six sanctuaries, five of which it owns. Two are located in the Aspen Parkland Ecoregion of the Prairie Ecozone, the other four are in ecoregions of the Boreal Plain Ecozone (Fig. 1 , Table 1). They vary in size from nearly 6.5 ha to 162 ha, and feature grasslands, bluffs, deciduous and coniferous forests, and wetlands. I will give an overview of each of the sanctuaries, starting from the south and moving north, and describe the ecological features and location as well as some results of the plant, bird, mammal, aquatic macroinvertebrate and lichen surveys.

The surveys were done as part of the Nature Sanctuary Inventory Project, initiated by Diana Bizecki Robson in 1997. This project is ongoing. While the survey data available to date are by no means complete, they are probably among the most extensive for any natural areas in the province. Fairly complete lists of birds have been compiled for Crooked Lake Fen, Van Brienen Land, Turtle Lake and Maurice G. Street Wildlife Sanctuary, with partial lists for the other sanctuaries. Vascular plant lists are available for all the sanctuaries. Lichen inventories have been done for all except Turtle Lake, (where a survey is planned for 2003) and aquatic macroinvertebrate surveys for all but Brandon Land and Maurice G. Street. Lists of mammals are available for Crooked Lake, Van Brienen Land and Turtle Lake, and a few mammals are listed for Rendek Elm Forest and Brandon Land. A list of reptiles and amphibians has been compiled for Turtle Lake and only one amphibian is listed for Rendek Elm Forest. Table 1 provides the references for survey information for each sanctuary. Most of the inventory information is unpublished and available only from the Nature Saskatchewan office in Regina. The exceptions are the lists of lichens at Crooked Lake Fen ${ }^{14}$ and vascular plants at Rendek Elm Forest ${ }^{7,19}$ published in Blue Jay, and the results of the aquatic macroinvertebrate surveys which are available on the internet at http:// www.usask.ca/biology/skabugs/index.html.

Nature Saskatchewan administers the sanctuaries as conservation areas, to prevent development, preserve habitat and for the enjoyment of its members and the general public. Although none are posted with "No Trespassing" signs, to prevent overuse, the areas are not advertised. People may visit the sanctuaries on their own. However, the stewards have an intimate knowledge of our sanctuaries and if visitors contact them previous to a visit, they often are glad to act as guides, time permitting.

\section{Crooked Lake Fen Nature Sanctuary}

Location and features (see Figure 2). This small sanctuary (less than 20 ha) contains a floating or "quaking" fen within the Qu'Appelle River Valley. The fen is an excellent example of a seepage fen, an uncommon habitat in Saskatchewan. Underground springs promote lush, varied vegetation which attracts birds during migration and the breeding season. The area also features a saline alluvial plain within a glacial valley, an oxbow of the Qu'Appelle River, a delta, a cattail marsh, steep valley 
Fig. 1. The Ecoregions of Saskatchewan (Map Source: The Ecoregions of Saskatchewan ${ }^{1}$ )

\section{Approximate locations} of the sanctuaries:

1 Crooked Lake Fen.

2. Van Brienen Land.

3. Brandon Land.

4. Rendek Elm Forest.

5. Turtle Lake

6. Maurice G. Street

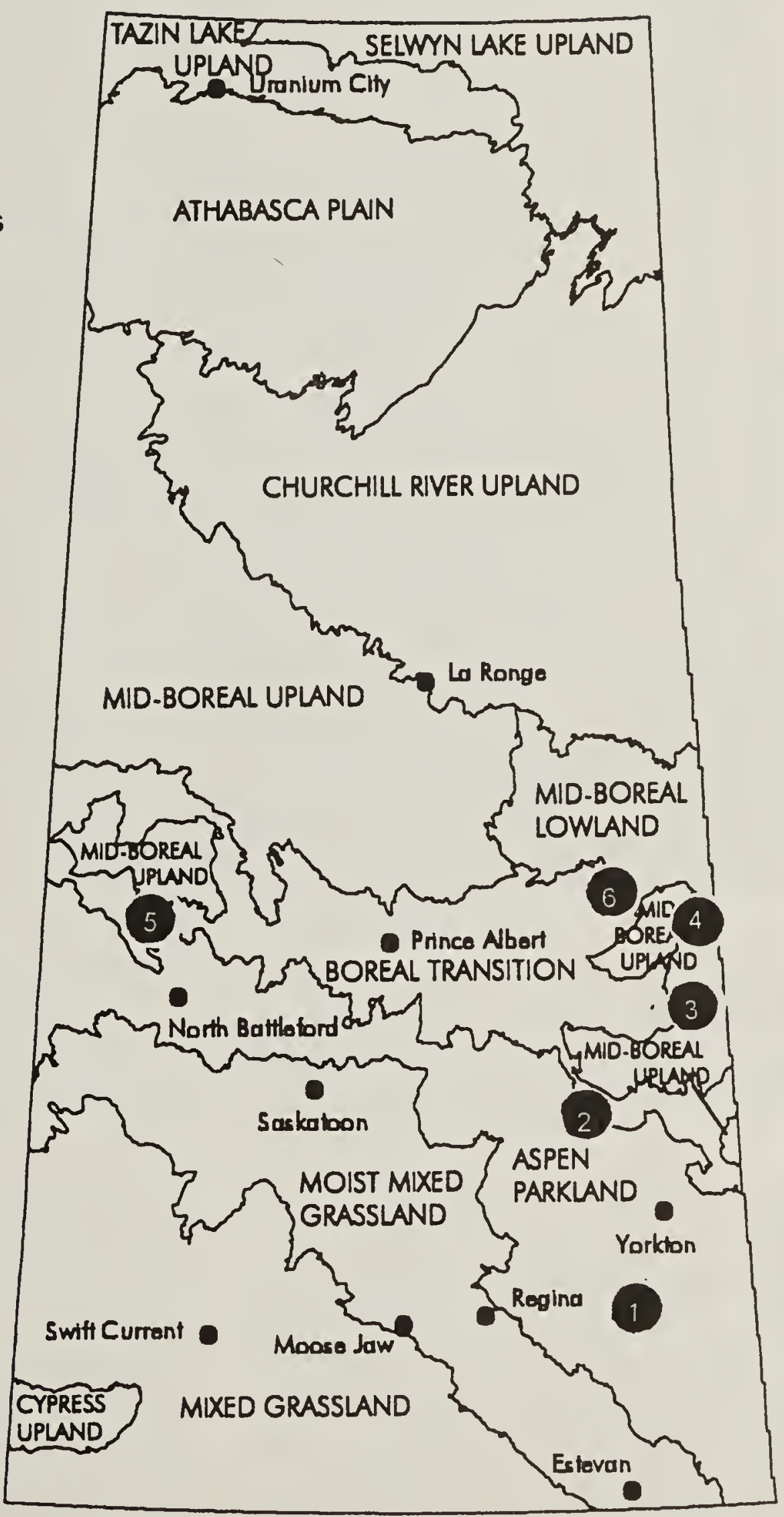




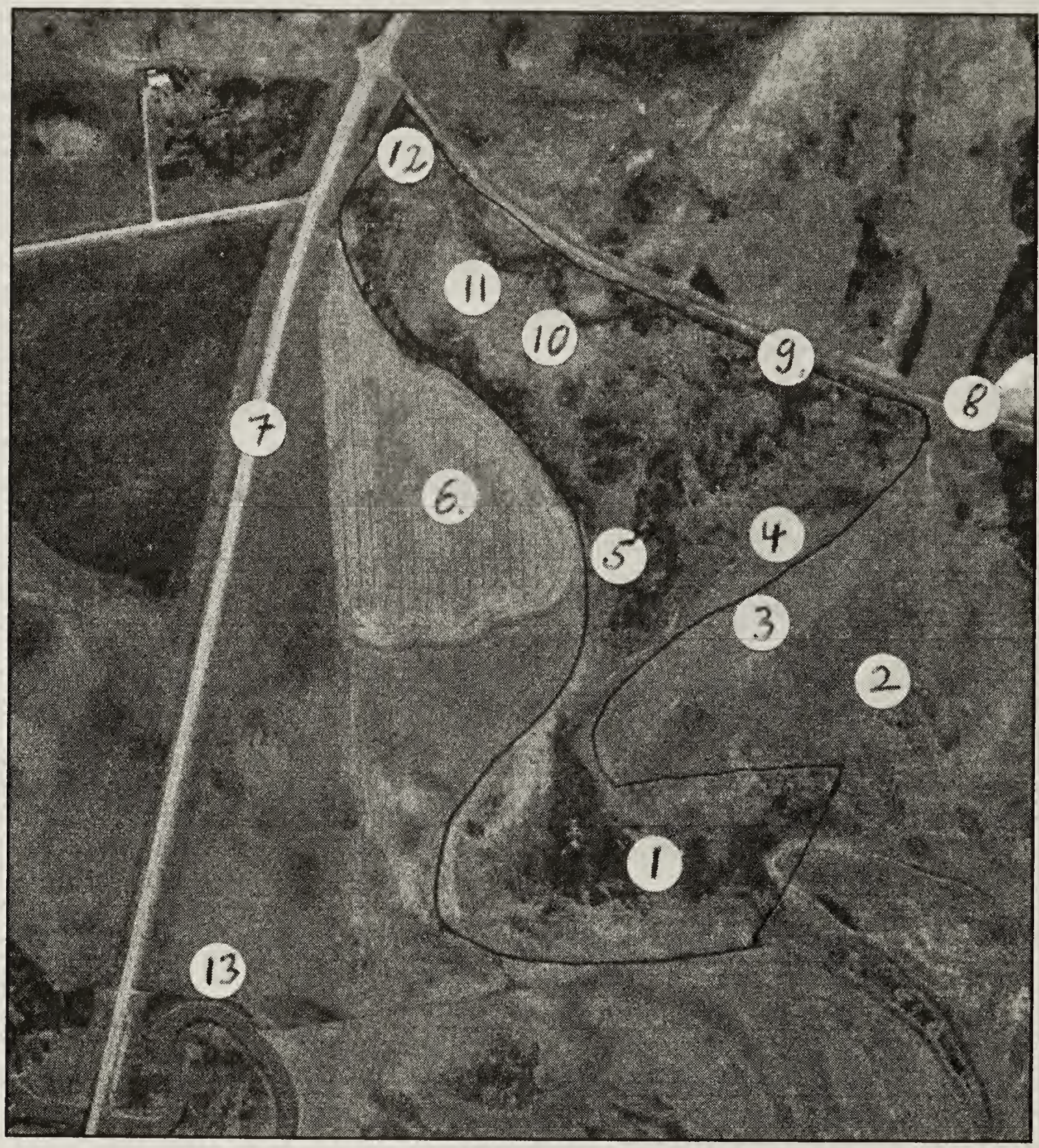

Fig. 2. Aerial View of Crooked Lake Fen Nature Sanctuary. Scale 1:10,000. †N

Legend: 1. Stream/Wet Marsh. 2. Hayland. 3. Approximate border of Sanctuary. 4. Wet marsh. 5. Wet meadow, River Birch dominant. 6. Cultivated field. 7. Highway 47. 8. Highway 247. 9. Hardwood forest, Balsam Poplar dominant. 10. River Birch stand. 11. Wet cattail marsh. 12. Manitoba Maple stand. 13. Qu'Appelle River.

slopes and an aesthetically pleasing "terraced garden." There are four other fens nearby which, along with the sanctuary, contain plant species found nowhere else in the Qu'Appelle Valley. The sanctuary is listed under the International Biological Program as the I.B.P. Area 71-3. ${ }^{2}$ Bernard de Vries reported further details. ${ }^{14}$

History. The site was purchased in 1988.
Stewards are John Pollock (306-735 2921) and Boyd Metzler (306-735 2380 or 306793 2911), both of Whitewood, SK.

Inventory highlights. The list of 57 species of birds for Crooked Lake Fen includes the Lazuli Bunting, Virginia and Yellow rails, Sora and four species of warblers. ${ }^{16}$ The 107 plant species include the rare Striped Coralroot (Corallorhiza striata) and Garber's Sedge 
(Carex garberi). ${ }^{16,25,26}$ The unique mix of 68 aquatic macroinvertebrate taxa include species which are 'typical of cool boreal streams and springs'. ${ }^{22-24}$ In 2002, 22 species of lichens were recorded, among them two rare lichens, the Boreal oakmoss lichen (Evernia mesomorpha Nyl.) and Punctured ramalina (Ramalina cfr. dilacerata (Hoffm.) Hoffm.). ${ }^{14}$ Lesser Burdock (Arctium minus) is one of the most conspicuous invasive plant species in the sanctuary. The barbs of mature seed heads can trap and kill warblers. ${ }^{29}$ A large population thrives along the south side of the ditch along Highway 247 and a few steps into the forest. Efforts are being made to control the spread by annually removing flower stalks.

To get there, drive from the junction of Highways 1 and 47 at Grenfell to about 30 km north on Highway 47 to Highway 247 just north of the bridge over the Qu'Appelle River. The sanctuary lies south and east of the junction and starts a few steps east of the junction with the stand of Manitoba Maple (Acer negundo). The boundaries are not marked.

To enjoy the sanctuary, walk around the periphery which takes 1 to 2 hours, depending on whether one crosses the creek at the narrow portion of the preserve. Start at the northwest corner, near the junction of Highways 47 and 247. From here (Brome Grass Meadow) and from the hill in the small native grassland, there is a beautiful view of the River Birch stand, the cattail marsh, and the Qu'Appelle Valley beyond. Walking south along the west margin of the sanctuary, there are mature Manitoba Maples on the east and a view of the valley to the south and west. Toward the southern tip of the maple forest, take a few steps through the shrubby vegetation to find the confluence of two small but swiftly flowing streams which meander south. Bird song is heard everywhere on a spring morning. In June 2001 , the meadow east and west of the narrow connection between the north and south portions was ablaze with False Dandelion (Agoseris glauca). ${ }^{26}$ After crossing the stream at the most narrow portion of the preserve and proceeding northeast along the Wet Marsh, you will find numerous, clear calcareous pools. Wandering along the ditch of Highway 247 and penetrating a few steps into the Balsam Poplar (Populus balsamifera) forest, the rare Striped Coralroot thrives. Please step carefully when exploring the sanctuary.

\section{Van Brienen Land Nature Sanctuary}

Location and features (see Figure 3). Located about $11 \mathrm{~km}$ southwest of Kelvington, this rectangular $(800 \mathrm{~m} \times 281$ $\mathrm{m})$ preserve covers 22.7 ha and includes 8.1 ha of cultivated land, 8.1 ha of lush woodland, and about 6.5 ha of Meadow Bank Lake. The lake lies adjacent to and north of the sanctuary and is approximately 2.4 $\mathrm{km} \times 0.4 \mathrm{~km}$. In the forties, the lake was dry, and the land was sold to adjacent landowners. A few years later it filled up again. Thus, Van Brienen Land includes a portion of the bottom of a lake. The forest is dominated by Balsam Poplar with a sprinkling of Aspen Poplar (Populus tremuloides) and Manitoba Maple, over a dense understory of Twining Honeysuckle (Lonicera dioica), Low-bush Cranberry (Viburnum edule) and numerous herbaceous plants. ${ }^{27}$ There is a small, shrubby meadow at the east end.

History. In 1906, Mr. and Mrs. William Harrison homesteaded the quarter section immediately west of the sanctuary. Their daughter, Sylvia van Brienen, bequeathed 22.7 ha of land valued at $\$ 8,400$ to Nature Saskatchewan on March 1, 1993.

Stewards are Brian Irving, Kelvington (306-327 4834) and Sandra MacDougal, Wadena (306-327 4816).

Inventory highlights. Brian Irving, who lives only $3.2 \mathrm{~km}$ from Van Brienen Land, has recorded the plants, birds and mammals in the sanctuary, on the lake and within a 4.8 $\mathrm{km}$ radius starting in $1965 .{ }^{27}$ In total, he has 


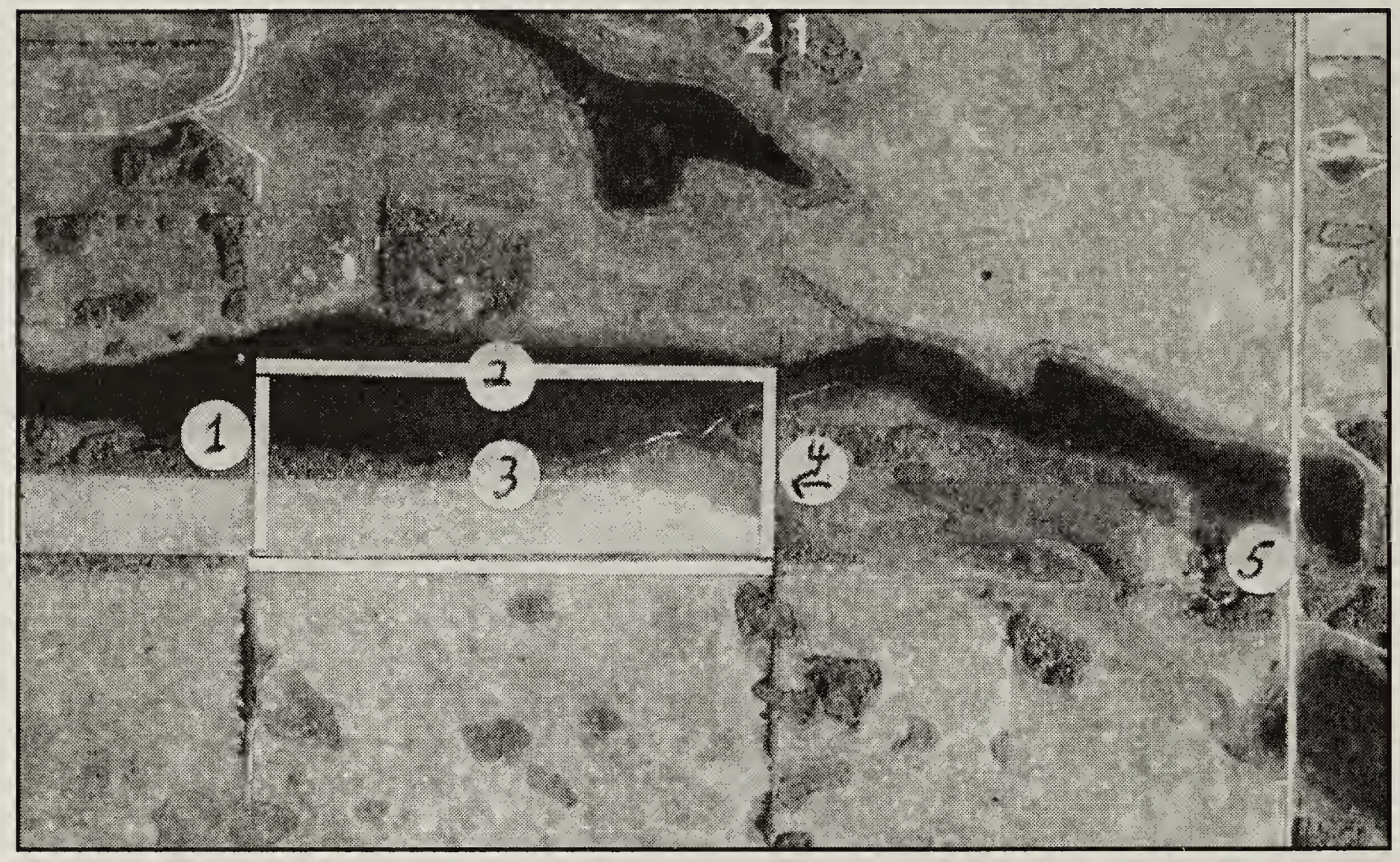

Fig. 3. Aerial view of Van Brienen Land Nature Sanctuary. Scale 1:20,000. IN Legend: 1. Border. 2. Meadow Bank Lake. 3. Forest. 4. Small meadow. 5. Access point by boat (see text)

observed 18 species of mammals or their tracks, and nineteen species of waterfowl which breed on the lake or in the sanctuary. The Least, Baird's and Pectoral Sandpipers stop at the lake during their migration from wintering grounds in the southern United States and South America and their breeding habitats in the arctic and subarctic. A total of 19 woody and 111 herbaceous plant species were recorded, of which 87 were native. The 20 identified lichen species include the Sunburst lichens (Xanthoria), often seen as colorful patches on Aspen and Balsam poplars. ${ }^{13}$ One of the 125 taxa of aquatic macroinvertebrates found in the Meadow Bank Lake is the Green Darner (Anax junius), a large dragonfly that migrates between this lake and central and northern states. ${ }^{23,24}$

To get there by land, you have to pass through fields owned by Leonard Harrison, brother of Sylvia van Brienen. Permission should be obtained by contacting steward Brian Irving. It is also possible to reach the sanctuary by canoe. Drive from the junction of Highway 35 and Hendon Road (which runs east-west through Hendon), $11.2 \mathrm{~km}$ east and $1.6 \mathrm{~km}$ north on grid road \# 665 to the east end of Meadow Bank Lake. From here, canoe $0.8 \mathrm{~km}$ to reach the sanctuary's eastern boundary. The boundaries are not marked.

To enjoy the sanctuary, it is best to enlist the guidance of Brian Irving. The narrow wildlife trails through thick undergrowth are not easy to find. Walking along the tranquil shore of the shallow lake, visitors may observe tracks, even those of moose, in the soft muck, a beaver lodge, and lichens on rocks and fallen trees. Deer frequent the meadow. For a few hours of enjoyment far from the "madding crowds" of cities and tourists, visit the Van Brienen Land Nature Sanctuary.

\section{Brandon Land Nature Sanctuary}

Location and features (see Figure 4). Perched on the east bank of a shallow valley and divided by Highway 49, the 6.47 ha property $(457 \mathrm{~m} \times 201 \mathrm{~m}$, minus the area of the highway), is located about $8 \mathrm{~km}$ east of 
Norquay and marked by a cairn on the north side of highway near the sanctuary's east border. The smaller portion on the north side of the highway is dominated by immature Aspen Poplar with some willow (Salix spp.) and tall shrubs, merging down the slope with a stand of White Spruce (Picea glauca). The larger southern portion, although logged some years ago, features some mature White Spruce with Aspen and Balsam poplars, and various tall shrubs. The west side touches on a series of swamps that together form Snake Creek where mature Black Spruce (P. mariana) and Tamarack (Larix laricina) flourish.

History. The preserve was donated to Nature Saskatchewan by Bette Brandon and Donna Green in memory of their parents, Lorne and Christine Brandon, who originally owned the land and are buried in the cemetery across the road from it. The sanctuary was formally dedicated by
Lionel Hughes on May 29, 1999 with the unveiling of a bronze plaque mounted on a cairn.

Stewards are Lionel and Michelle Hughes, Norquay, SK (306-594 2455) and David Weiman, Preeceville, SK (306-547 4661).

Inventory highlights. Vern Harms compiled a list of 112 vascular plants, only five of which are introduced. ${ }^{18}$ Garth Nelson, David Weiman and Lionel Hughes recorded four bird and two mammal species. ${ }^{21}$ Twenty-five lichen species in 14 genera were recorded, including species representative of the boreal forest and the prairies, reflecting the sanctuary's location in the Boreal Transition Ecoregion. ${ }^{11}$

To get there, drive about $8 \mathrm{~km}$ east of Norquay on Highway 49 and watch for the above mentioned cairn on the north side of the road.

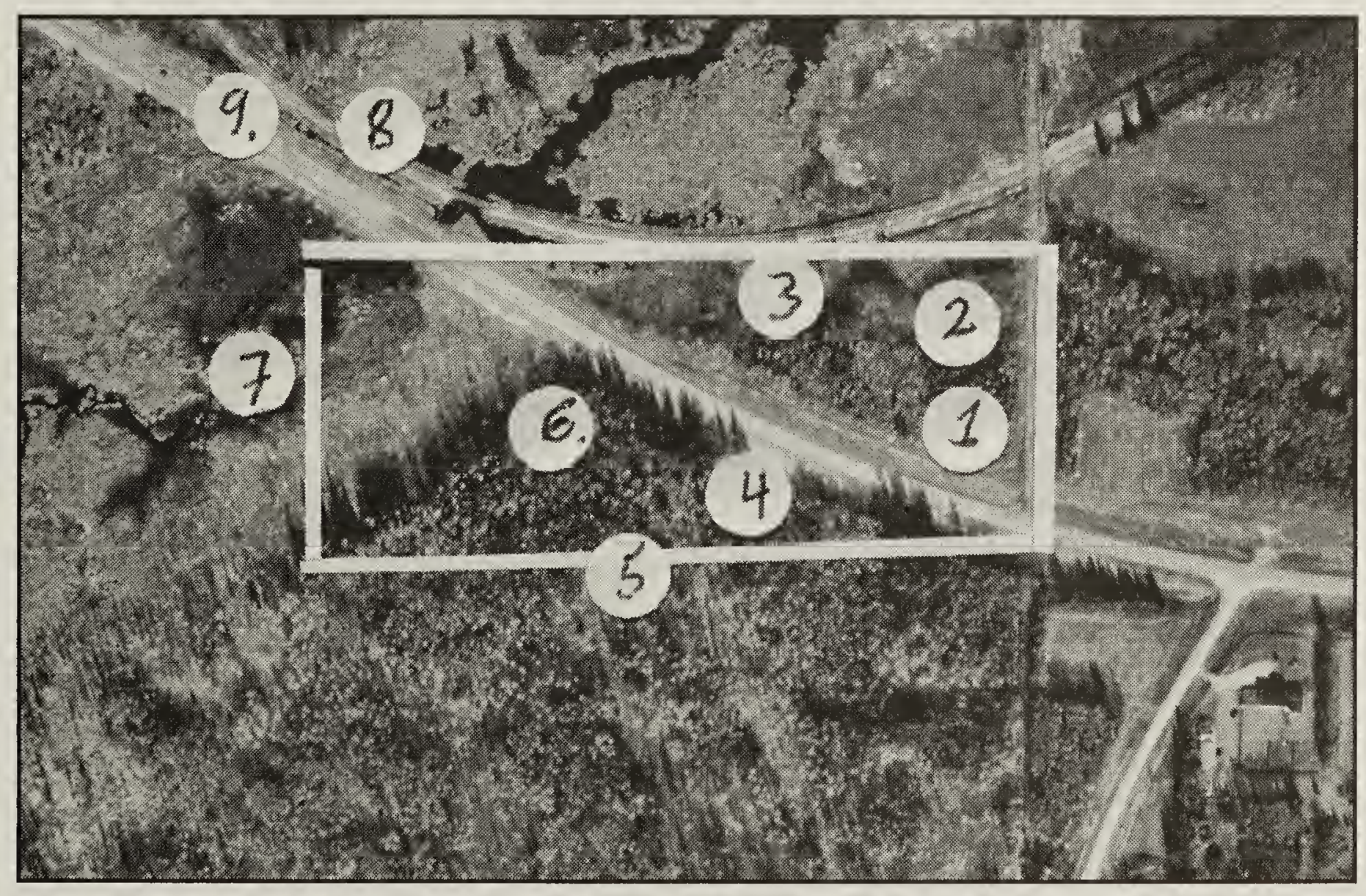

Fig. 4. Aerial view of Brandon Land Nature Sanctuary. Scale 1:8,000. iN Legend: 1. Cairn marker. 2. Immature Aspen poplar. 3. Second growth White Spruce. 4. Second growth White Spruce and Balsam Poplar with some mature spruce and poplars. 5. Sanctuary border. 6. Black Spruce and Tamarack in wet places. 7. Snake Creek. 8. Railroad track. 9. Highway 49. 
To enjoy the sanctuary, put on good hiking boots and suitable clothing because there are no formal trails. Be prepared for dense understory, and on the west side, look out for swampy areas especially in the portion south of the highway.

\section{Rendek EIm Forest Nature Sanctuary}

Location and features (see Figure 5). The Rendek Elm Forest Nature Sanctuary is 14.2 ha in size and located about $24 \mathrm{~km}$ northeast of Hudson Bay at the confluence of Smoking Tent Creek and the Red Deer River. The area floods periodically. Mature American Elm (Ulmus americana) cover about $75 \%$ of the land; Manitoba Maple and Balsam Poplar are concentrated on the east side. Tall shrubs, such as Red-osier Dogwood (Cornus stolonifera) and High-bush Cranberry (Viburnum trilobum) form the woody understory. A striking feature is the luxurious Ostrich Fern (Matteuccia struthiopteris) that forms the dominant part of the understory over large areas of the elm forest. Spotted
Joe-pye Weed (Eupatorium maculatum) and Tall Meadow-rue (Thalictrum dasycarpum) thrive along the semi-open river bank. ${ }^{6}$ Unfortunately, in 1999 two elm trees were found infected by Dutch Elm disease. 7, 19,20 By 2002, the disease had spread to six trees in as many groups of elms (Alex Rendek, 2002, pers. comm.). Nature Saskatchewan considered it financially and environmentally irresponsible to attempt to control Dutch Elm Disease here, and it was decided to let nature take its course. It is hoped that Manitoba Maple and Balsam Poplar will fill the gaps left by the dying elms. The trails will be kept open and as safe as possible.

History. In 1989, Don Hooper persuaded the owner, Alex Rendek, to sell the area to Nature Saskatchewan and the Saskatchewan Wildlife Federation. The sanctuary was officially opened in 1991. Nature Saskatchewan is responsible for administering the preserve.

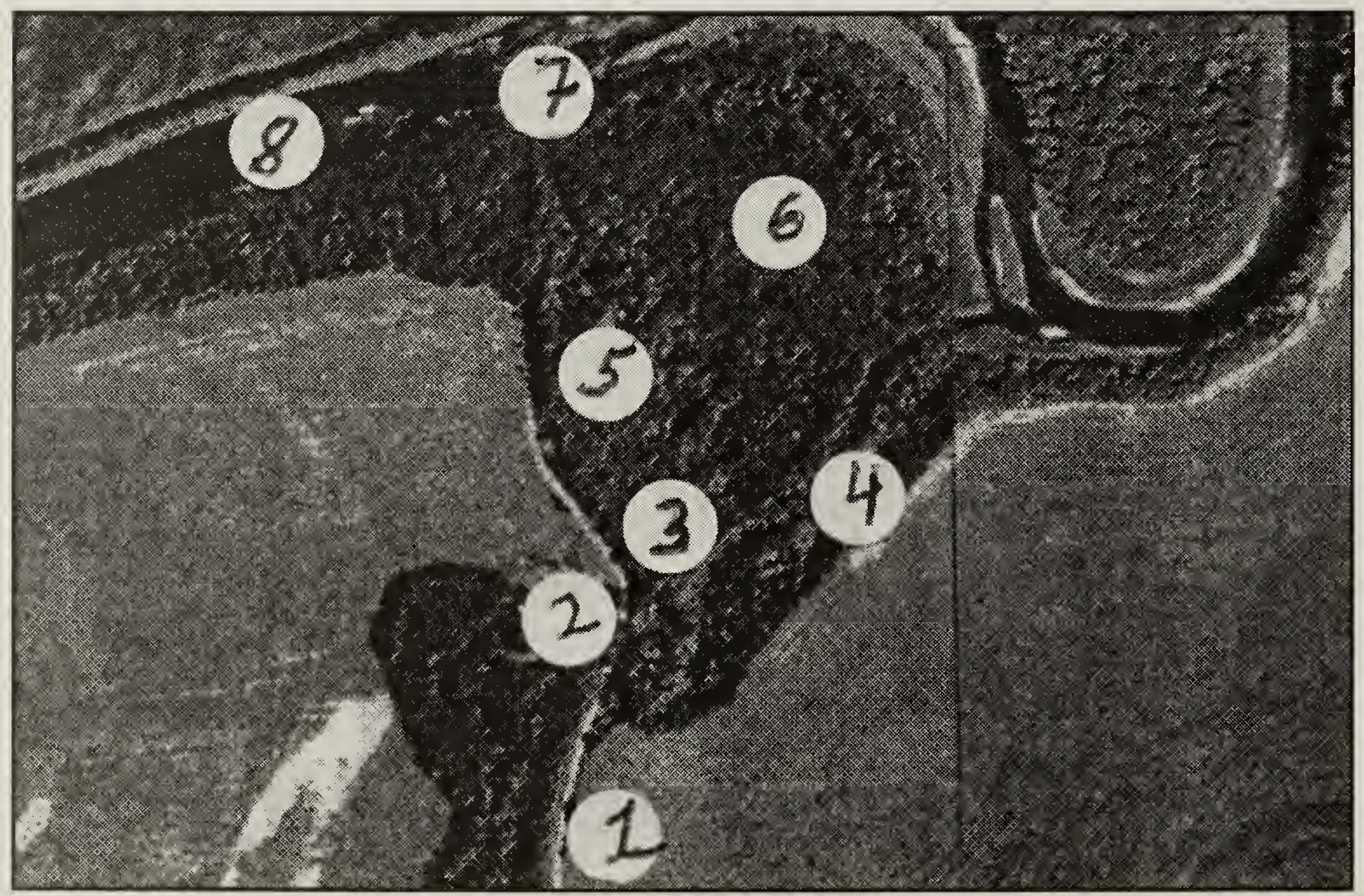

Fig. 5. Aerial view of Rendek Elm Forest Nature Sanctuary (Courtesy of Weyerhaeuser). Scale approximately $1: 12,000$. iN

Legend: 1. Access road. 2. Bridge over Smoking Tent Creek. 3. Nodding Trilliums. 4. Smoking Tent Creek. 5. Manitoba Maple Forest. 6. Mature American Elm and Ostrich Fern. 7. Sinall parking area. 8. Red Deer River. 
Stewards are Alex Rendek (306-865 3147) and Moe Alain (306-865 3266), both of Hudson Bay, SK.

Inventory highlights. Seventy-eight plant species were recorded in the sanctuary, including five species considered rare in Saskatchewan: Smooth Yellow Violet (Viola pubescens), Blue Monkey-flower (Mimulus ringens), Assiniboia Sedge (Carex assiniboinensis), Nodding Trillium (Trillium cernuum), and Red Elderberry (Sambucus racemosa spp. pubens). ${ }^{7,19}$ The list of birds includes 196 species that likely occur in the sanctuary according to the Atlas of Saskatchewan Birds, only 8 of which have actually been observed in the sanctuary because little time has been spent bird watching. ${ }^{6,28}$ Twenty-two lichen species have been identified. ${ }^{12}$ In the Red Deer River adjacent to the sanctuary, 172 taxa of aquatic macroinvertebrates were identified, the highest number among similar surveys carried out in three other Nature Saskatchewan sanctuaries. This reflects the typically greater diversity of species in lotic (flowing) aquatic habitats than in lentic (still) aquatic habitats. ${ }^{22-24}$

To get there, drive east from Hudson Bay on Highway 3 . After about $14 \mathrm{~km}$, just east of where Smoking Tent Creek crosses the highway, there is a white sign on the north side of the road pointing to the Rendek Elm Forest. Travel north on a gravel road for about $4.8 \mathrm{~km}$ to the sign marking the entrance.

To enjoy the sanctuary, park in the small parking lot located in the northwest corner near the Red Deer River and follow the marked trail. You may feel dwarfed by the elms, many of them towering up to $23 \mathrm{~m}$, and Ostrich Ferns which reach over even a tall person in some locations. Occasionally, the trail leads to lookout points above the Red Deer River and Smoking Tent Creek. This is bear country, so make some noise on your walk. Brochures are available from the Hudson Bay town office.

\section{Turtle Lake Nature Sanctuary}

Location and features (see Figure 6). The 48.5-ha Turtle Lake sanctuary is located about $35 \mathrm{~km}$ northwest of Glaslyn along the east shore of Turtle Lake, between the resort beaches of Turtle Lake Lodge and Indian Point. It features cliffs with a lookout (\#3, Fig. 6) $12 \mathrm{~m}$ above water level, upland mixed forest dominated by Aspen Poplar and White Spruce, an open meadow and a gravel pit that is slowly revegetating (\#8, Fig. 6). A boreal wetland and a small sand spit near shore are frequented by many birds. A small pond provides habitat for toads and frogs (\#9, Fig. 6). In the meadow, Smooth Brome (Bromus inermis) is crowding out native vegetation and the area may be mowed to suppress its growth. ${ }^{9}$

History. In 1993, Muriel Carlson and E. Merle Robinson initiated a preservation campaign for this land. With funds donated by Nature Saskatchewan members, resort dwellers, the general public, Cameco Corporation and Wascana Energy, the site was purchased from Saskatchewan Wildlife Habitat Trust. The official opening occurred on 12 June 1994. Once it became a sanctuary, the stewards found it difficult to restrict all-terrain vehicles (ATV's), so they developed an ATV trail just south of the sanctuary on the east-west road allowance that meets the paved grid road. The trail continues north in the ditch, then angles across the northeast corner of the sanctuary to meet the trail to the Turtle Lake Lodge. Users must stay on the trail or lose the privilege (M. Carlson, 2003, pers. comm.). In June 2002, the huge James Fire raged on the west side of the lake. Firefighting helicopters and storage areas were located in the southwest corner of the sanctuary, where many temporary campsites accommodated fire fighters for 23 days. Muriel managed to flag the orchid sites to prevent them from being trampled. ${ }^{10}$

Stewards are Muriel Carlson, Livelong, SK (306 845 3227), E. Merle Robinson, 


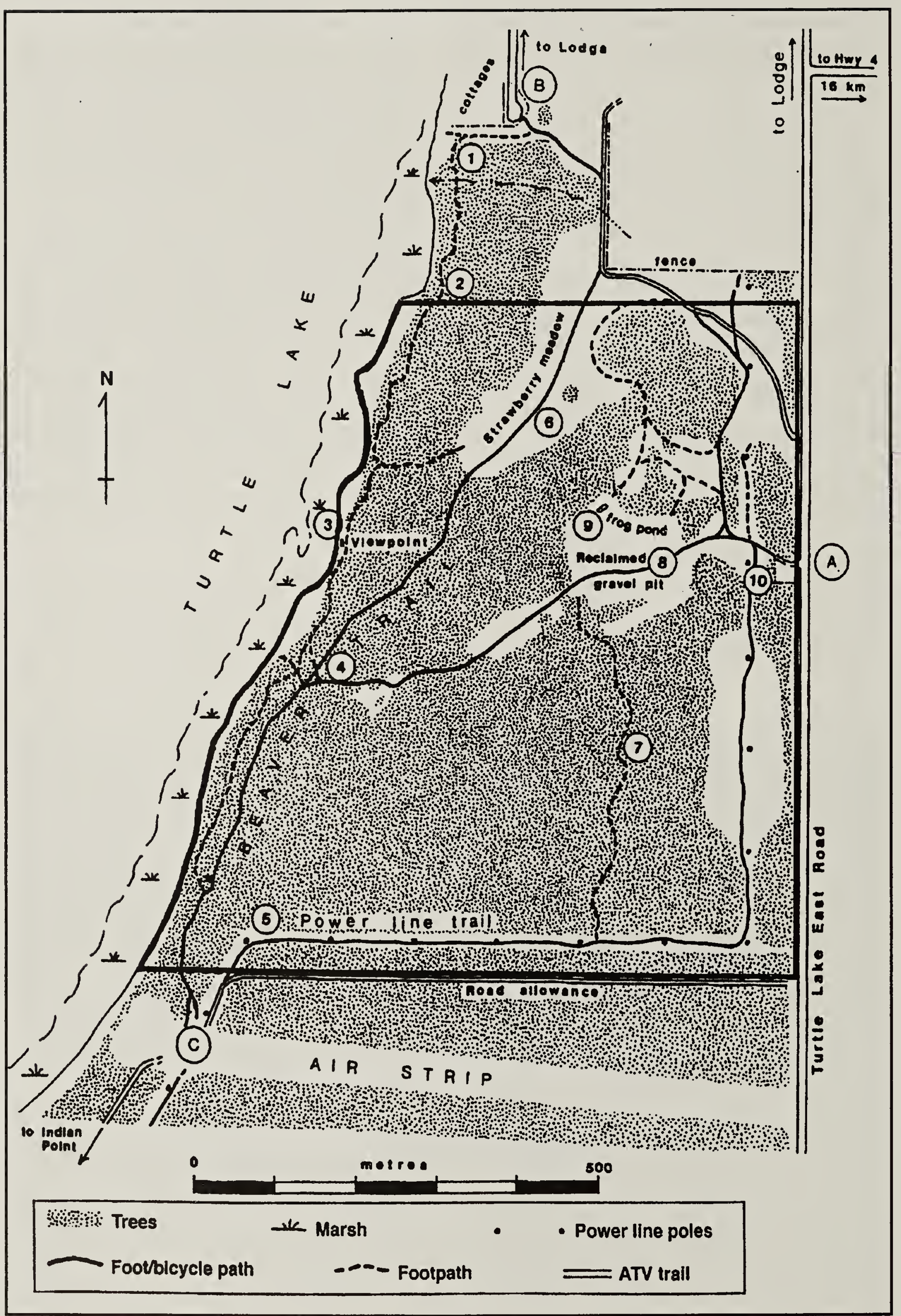

Fig.6. Map of Turtle Lake Nature Sanctuary showing boundary, trails and other features. Letters $A-C$ and numbers $1-10$ refer to a detailed description of the trails in the broch ure A Self Guiding Tour of the Turtle Lake Nature Sanctuary. 
Livelong, SK (306 845 2857) and Michael Williams, Saskatoon (306 242 5383).

\section{Inventory highlights}

At least 167 species of vascular plants have been identified, including 7 trees, 26 shrubs and 138 herbs. ${ }^{5}$ There are nine species of orchids, including Franklin's Lady's-slipper (also called Northern or Sparrow's-egg Lady's-slipper, Cypripedium passerinum) and Striped Coralroot. ${ }^{17}$ Leather-leaved Grape Fern (Botrychium multifidum) occurs along the Power Line Trail. ${ }^{9}$ One hundred and seventy-seven bird species have been seen within the preserve and on adjacent Turtle Lake. ${ }^{5}$ The sanctuary, on the path of one of North America's major bird migration routes, experiences waves of passerines every May. ${ }^{17}$ The forests are home to 18 species of mammals typical of boreal areas. ${ }^{5}$ In addition, Muriel (M. Carlson, 2003, pers. comm.) has observed Mule Deer, Elk, Muskrat, Wolf and Fisher. She also reported the probable sighting of a Cougar. One snake, Western Plains Garter Snake (Thamnophis radix haydeni) and three amphibians have been recorded, including the Boreal Chorus Frog (Pseudacris triseriata maculata), Wood Frog (Rana sylvatica) ${ }^{5}$ and Canadian Toad (Bufo hemiophrys) (M. Carlson, 2003, pers. comm.). Surveys of the aquatic invertebrate fauna in 2000-2002, yielded 101 taxa in Turtle Lake adjacent to the sanctuary, and an astonishing 76 in the Frog Pond, which covers only 7 square metres. ${ }^{22-24}$

To get there, drive about $25 \mathrm{~km}$ north from Glaslyn on Highway 4, then head west on a gravel road to Turtle Lake. The road terminates near the lake after about $16 \mathrm{~km}$. From this "T" junction, drive south for about 600 metres to the parking lot on the west side of the road (Fig. 6, \#10).

To enjoy the sanctuary, pick up the brochure "A Self Guiding Tour of the Turtle Lake Nature Sanctuary" from the Nature Saskatchewan office or Turtle Lake Lodge located just north of the sanctuary. Most trails are for foot traffic only; bicycles are allowed where indicated and there is a short trail in the northeast portion where ATV's are allowed. The best birding at Turtle Lake is along the power cut-lines (\#5, Fig. 6) (M. Carlson, pers. comm) and the Beaver Trail (\#4, Fig.6). ${ }^{8} \mathrm{~A}$ walking tour takes about 2 hours.

\section{Maurice G. Street Wildlife Sanctuary}

Location and features (see Figure 7). The 162 ha preserve, $17 \mathrm{~km}$ northeast of Nipawin, covers the portion of section 152-14-W2 that lies east of the Saskatchewan River, plus the south half of section 12-5214-W2 south of the Saskatchewan River. Maurice G. Street Wildlife Sanctuary features ancient flood-plain terrain as well as high ground overlooking the Saskatchewan River. It is heavily wooded with Tamarack, Balsam Fir (Abies balsamea), White Spruce, and Balsam and Aspen poplars. Jack Pine (Pinus banksiana) is dominant on the sandy upland soil. The Large Yellow Lady's-slipper (Cypripedium calceolus var. pubescens) and the rare Ram's-head Lady's-slipper (Cypripedium arietinum) grow in several locations. ${ }^{4}$

History. Stan Riome and Doug Phillips initiated the project to preserve the area. The Saskatchewan Natural History Society established the sanctuary in 1968, and aptly named it after Maurice Street (1910-1966), an ardent, self-taught naturalist of the Nipawin area. In his short life, Maurice identified over 245 bird species, collected the eggs of over 100 , found the nests of 142 species, banded 13,214 individual birds and published over 28 papers in the Blue Jay. ${ }^{3}$ Nature Saskatchewan has leased this property from Saskatchewan Environment since 1967 and is responsible for paying taxes and for general stewardship.

To get there, drive $6 \mathrm{~km}$ east on Highway 55 from the RCMP-KFC corner in Nipawin. Turn north onto a well-maintained road (which becomes a trail) and proceed for about $11 \mathrm{~km}$. At the "T" junction, turn east (right) and then follow the trail as it turns 


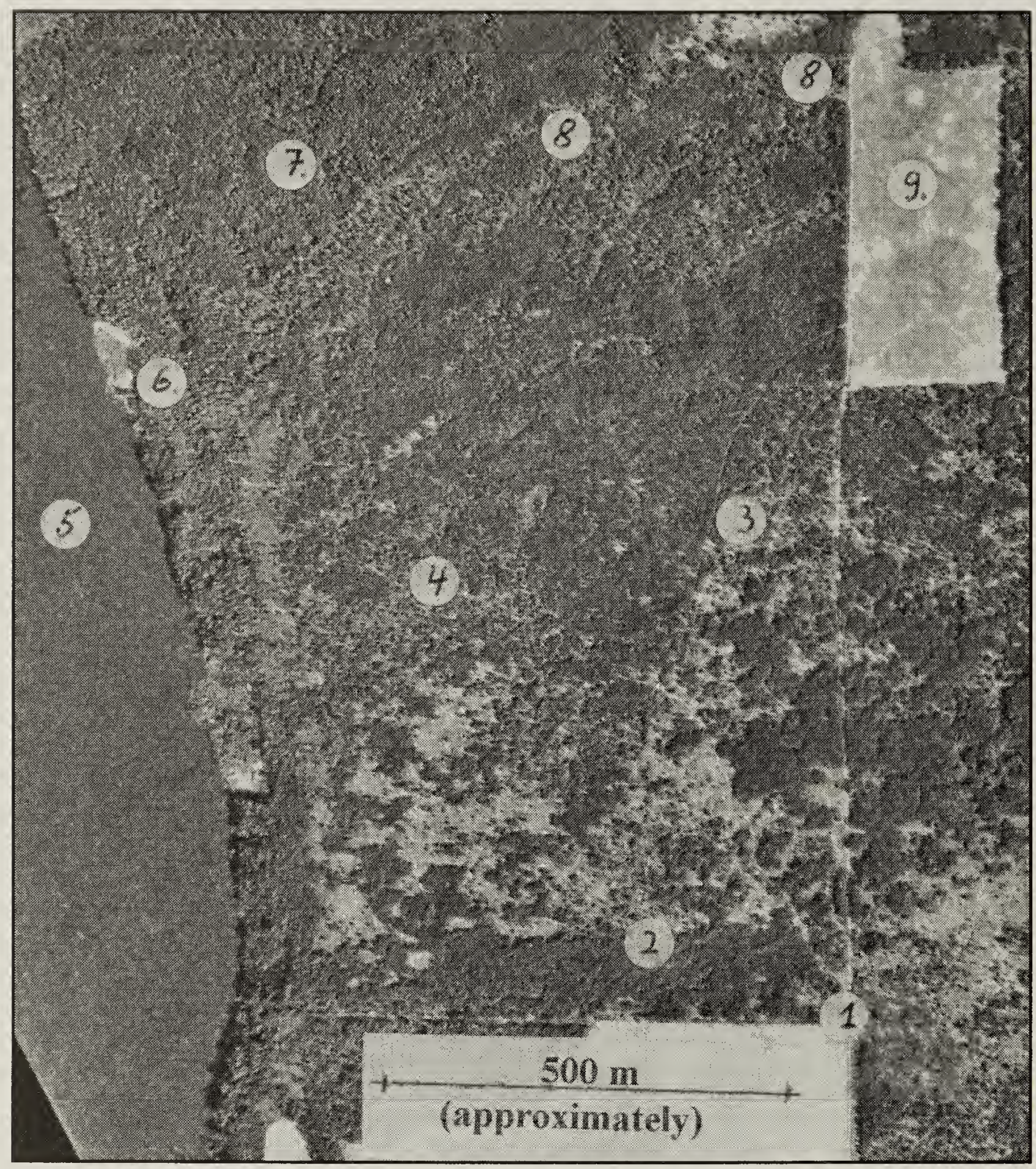

Fig. 7. Aerial view of Maurice G. Street Wildlife Sanctuary. iN

Legend: 1. Entrance sign, and south and east border. 2. West Corner trail. 3. Gerbil trail. 4. Look-off trail. 5. Saskatchewan River. 6. Look-off point. 7. Fern forest trail. 8. Log cabin trail. 9. Formerly cultivated, now regenerating forest land, owned by Doug (steward) and Shirley Phillips.

north (left) to reach the large entrance sign to the sanctuary.

Inventory highlights. About 65 vascular plant species are recorded for the sanctuary. ${ }^{4}$ The list of 57 bird species includes Bald and Golden eagles, Common Loon, American Redstart and Pileated Woodpecker. ${ }^{30}$ Fiftyfive lichen species in 21 genera were identified in $2002 . .^{15}$

To enjoy the sanctuary, use the trails starting at the wooden entrance sign. Walking northwest through a tall Jack Pine forest leads to the "Look-off" point with a magnificent, panoramic view of the Saskatchewan River, which widens to become Tobin Lake. Silverberry flowers 


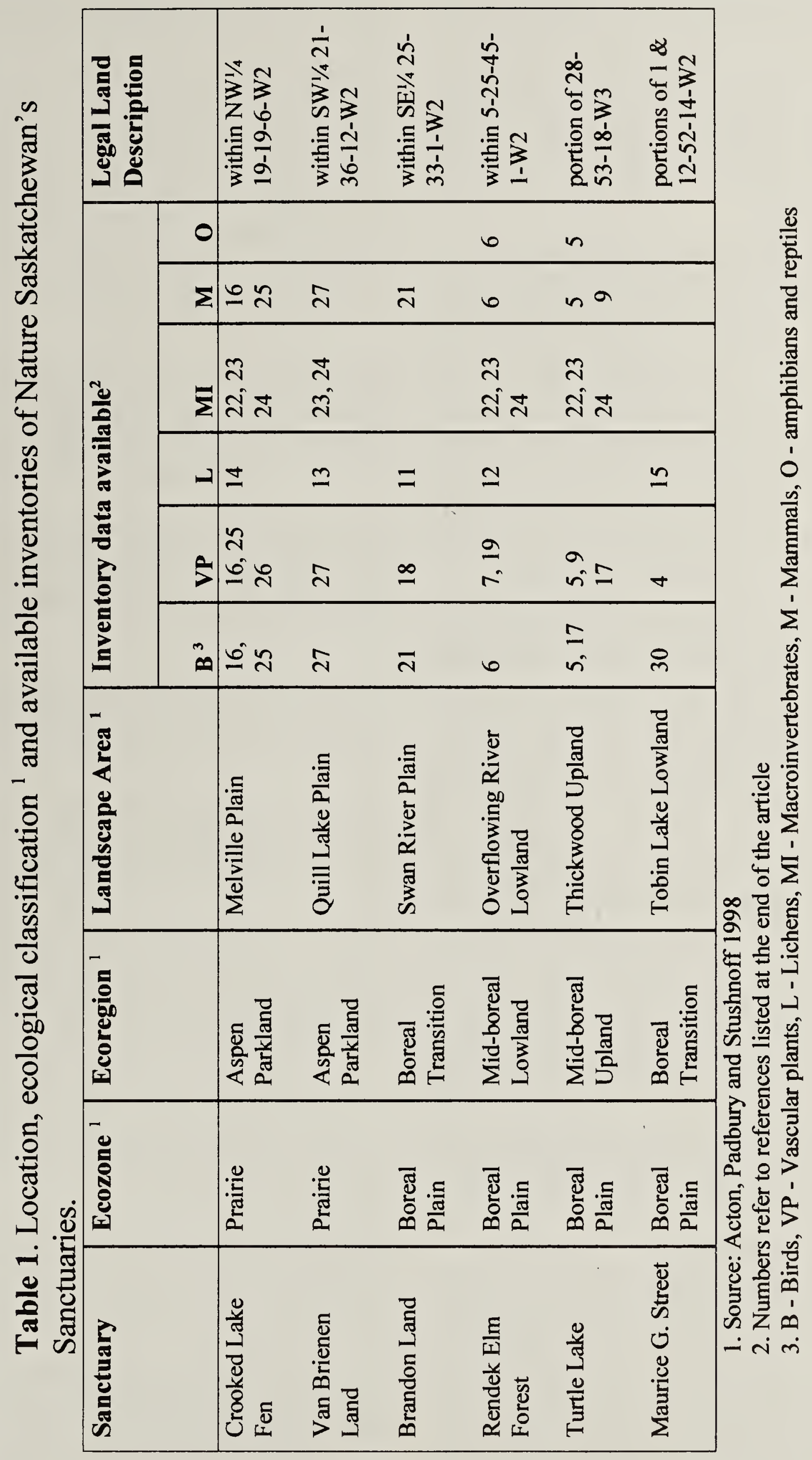


(Elaeagnus commutata) fill the air with their fragrance in June. From the "Lookout," the Log Cabin Trail leads northeast out of the sanctuary to the private land of Doug and Shirley Phillips. Walk slowly and you might see the unexpected such as the beautiful Polyphemus Moth (Anthraea polyphemus).

\section{Discussion}

Some people believe that large natural areas such as Maurice G. Street Wildlife Sanctuary are more valuable than small ones, such as Crooked Lake Fen or Van Brienen Land. While it is certainly true that the larger the preserve, the more wildlife is protected, small areas still have value. When a visitor hikes in June along the margins of Crooked Lake Fen, or along the shore adjoining Van Brienen Land, the great variety of bird song is testimony that many species make their homes here.

The flora and fauna of the sanctuaries reflect their different locations from the Aspen Parkland Ecoregion to the Boreal Transition, Mid-boreal Upland and Mid-boreal Lowland Ecoregions. For example, at Van Brienen Land, poplars constitute the forest, while at Maurice G. Street, Jack Pine and White Spruce are dominant, and at Turtle Lake, a mixed forest of broadleaf and evergreen trees prevails. The lichen flora and the diversity of the macroinvertebrate fauna both indicate that water and ambient air are healthy in the four sanctuaries where surveys for these species have been made. Lichens were most frequent in the Maurice G. Street Sanctuary, probably because of the relatively open canopy. ${ }^{15}$ All the surveys, but perhaps particularly those for lichens and macroinvertebrates, constitute good baseline data.

\section{Acknowledgments}

Thanks are due to the stewards Muriel Carlson, Lionel Hughes, Brian Irving, Boyd Metzler, Doug Phillips, John Pollock and Alex Rendek for reviewing sections of the manuscript, to Diana Bizecki Robson and Anna Leighton for many helpful editorial improvements, to Bernard de Vries for information on the Brandon Land Nature Sanctuary, to Anna Leighton for suggesting the topic and to the staff of the Nature Saskatchewan office for their support. Much of the information on features and locations was taken from summaries that the late Garth Nelson prepared for each sanctuary and are filed at the Nature Saskatchewan office in Regina. Many of the surveys, in particular those for aquatic macroinvertebrates and lichens were sponsored by SaskEnergy.

1. ACTON, D.F., G.A. PADBURY and C.T. STUSHNOFF. 1998. The Ecoregions of Saskatchewan. Canadian Plains Research Center. University of Regina. XII + 204 pp.

2. ADAM, C.I.G. 1985. Natural areas in Saskatchewan, A review of the IBP System. Report prepared for the Saskatchewan Natural History Society.

3. ANONYMOUS. 1988. Uncertain future for wildlife sanctuary. The Northeast Region Community Booster. V. 17, No. 23.

4. BIZECKI ROBSON, D. 1999. Plants of the Maurice Street Nature Sanctuary. List compiled for Nature Saskatchewan. 4pp

5. BIZECKI ROBSON, D. 1999. Ecological Inventory of the Turtle Lake Nature Sanctuary. Report prepared for Nature Saskatchewan. 14 pp.

6. BIZECKI ROBSON, D. 2000. Ecological Inventory of the Rendek Elm Forest Nature Sanctuary. Report prepared for Nature Saskatchewan. 11 pp.

7. BIZECKI ROBSON, D. and V. HARMS. 2000 . New vascular plant finds at the Rendek Elm Forest. Blue Jay 58:89-94.

8. CARLSON, M. 1991. Turtle Lake, Saskatchewan: A boreal oasis. Canadian Birding 2:19-24. 
9. CARLSON, M. 2001. Turtle Lake Nature Sanctuary. Our 2001 Summer. Nature Views. Issue 128. Winter 2001

10. CARLSON, M. 2002. Fire at the Turtle Lake Sanctuary. Nature Views. Issue 132. Winter 2002.

11. DE VRIES, B. 2002. Lichen Inventory of the Brandon Land Nature Sanctuary. Report prepared for Nature Saskatchewan. $9 \mathrm{pp}$.

12. DE VRIES, B. 2002. Lichen Inventory of the Rendek Elm Forest Nature Sanctuary. Report prepared for Nature Saskatchewan. 9 pp.

13. DE VRIES, B. 2002. Lichen Inventory of the Van Brienen Land Nature Sanctuary. Report prepared for Nature Saskatchewan. 9 pp.

14. DE VRIES, B. 2003. Lichen Inventory of the Crooked Lake Fen Nature Sanctuary. Blue Jay 61:43-50.

15. DE VRIES, B. 2003. Lichen Inventory of the Maurice Street Wildlife Sanctuary. Report prepared for Nature Saskatchewan. $10 \mathrm{pp}$.

16. GOLDER ASSOCIATES LTD. 1995. Report on the Crooked Lake Fen Avifauna and Vegetation Survey. Report prepared for SaskEnergy. 20 pp.

17. GRANT, M. 2001. Sanctuary. Saskatchewan Naturally 3 (1):29-33.

18. HARMS , V. 1999. List of vascular plants recorded from the Brandon Land Nature Sanctuary. List compiled for Nature Saskatchewan. 5 pp.

19. HARMS, V. and L. BAKER. 1998. A preliminary floral list for the Rendek Elm Forest Nature Sanctuary in east-central Saskatchewan. Blue Jay 56:213-215.
20. HUGHES, L. 2001. What lies beneath the bark. Saskatchewan Naturally 3 (3):2631.

21. NELSON, G., D. Weiman and L. Hughes. 1999. List of animals recorded from the Brandon Land Nature Sanctuary. Report prepared for nature Saskatchewan. 1 p.

22. PARKER, D. 2000. Preliminary aquatic insect survey results of the Nature Saskatchewan Sanctuaries. Report prepared for Nature Saskatchewan. 8 pp.

23. PARKER, D. 2001. Aquatic macroinvertebrate survey of Nature Saskatchewan Sanctuaries. Report prepared for Nature Saskatchewan. 29 pp.

24. PARKER, D. 2002. Aquatic macroinvertebrate survey of Nature Saskatchewan Sanctuaries. Report prepared for Nature Saskatchewan. 25 pp.

25. PESCHKEN, D.P. 2000. Ecological Inventory of the Crooked Lake Fen Nature Sanctuary. Report prepared for Nature Saskatchewan.14 pp.

26. PESCHKEN, D. P. 2001. A Visit to the Crooked Lake Fen Sanctuary. Nature Views. Issue 127. Fall 2001.

27. PESCHKEN, D.P. 2001. Ecological Inventory of the Van Brienen Land Nature Sanctuary. Report prepared for Nature Saskatchewan.12 pp.

28. SMITH, A.R. 1996. Atlas of Saskatchewan Birds. Saskatchewan Natural History Society. Regina, SK. 456 pp.

29. UNDERWOOD, T. 2001. Observations on Burdock-killed Birds in King's Park, Winnipeg, MB. Blue Jay 59:64-69.

30. WALKER, J. 2001. Avifauna Survey of the Maurice Street Sanctuary. Report prepared for Nature Saskatchewan. 9 pp. 